\title{
宮城県中部㧍よび北部に分布する 後期更新世広域テフラとその層位
}

\author{
八木 浩司 ${ }^{*}$ 早 田 勉 ${ }^{* *}$
}

\section{A stratigraphical study on the Late Pleistocene widespread tephras occurring in central and northern part of Miyagi Prefecture}

\author{
Hiroshi YAGI ${ }^{*}$ and Tsutomu SoDA **
}

\begin{abstract}
Abstrart
Widespread Tephra is a valuable time marker for tephrochronology and archaeology. Several fine ash fall deposit are distributed in central and northern part of Miyagi Pref.. The authors have correlated them to widespread tephras by means of following methods. They are lithological description of tephras, measurements of refractive indices of glass shards and heavy minerals, and analyses of major elements chemical composition of glass shards using a microprobe analyzer. As a results, four late Pleistocene widespr ead tephras are discovered in this study area. They are AT, Aso-4, On-PmI and Toya. The authors described the stratigraphic positions of those widespread tephras in detail. And furthermore, they mentioned the significance that four late Pleistocene widespread tephras were discovered in this study area. The results are summarized as follows.

1) In central part of Miyagi Pref., the stratigrafic sequence of AT ash, Kawasaki scoria layer, Aso-4 ash and Medeshima pumice layer occur in ascending order is confirmed. Kawasaki scoria and Medeshima Pumice are valuable marker tephras in that region.

In northern part of Miyagi Pref., 10 tephras or tephra formations and their stratigraphic positions are recognized. They are, in ascending order, Hijiori pumice layer, Narugo • Katanuma-Uehara tephra, AT ash, Narugo-Yanagisawa tephra layer, Aso-4, Narugo-Nisaka tephra layer, Kitahara ash layer, On-PmI, Toya ash and Ichihasama pumice layer. Consequently, the late Pleistocene tephra stratigraphy in Miyagi Prefecture is linked with those in central and southwestern part of Japan.

2) The stratigraphic relation between On-PmI and Toya ash is revealed for the first time to implicate the occurrence of marine terrace developed in ca $100 \mathrm{ka}$ in a tectonically active region.
\end{abstract}

\footnotetext{
* 防衛大学校 - 地球科学教室 Department of Geoscience, National Defense Academy

**パリノ・サーヴェイ (株) 研究所 Institute of Palynosurvey Co., Ltd.
} 


\section{I. はじめに}

近年, 後期更新世の広域テフラに関する知見が集積されてきた (町田ほか $1985 ， 1987$ ほか多数)。広域 テフラは, 多くの放射年代資料に加えて, 本邦沿岸諸地域に発達する同地形面としての海成面及びその構 成層との層序関倸をもとに，沉世界的な海面変動に対応する時間スケールで噴出時期が与えられている。 このため, 信頼性の高い噴出時期が明らかとなった 広域テフラとの層序関係から従来年代不詳のローカル な示標テフラについても，その噴出時期を推定することが可能となってきた。

宮城県内においても蔵王，鳴子，鬼首，栗駒の 各火山周辺部で複数の後期更新世の示標テフラが認めら れてきた（表 1)。それらの示標テフラの多くは，地形発達史的関心のみならず，最近宮城県内で発見の相 次ぐ前期旧石器の編年学的関心から放射年代が得られている（板垣ほか'1981；市川 1983，1986，1987； 輿水 1983，1986，1987ほか多数)。しかしそれらの年代值は，ばらつきが大きいことから，信頼性に不安 が女った。このため宮城県に分布する示標テフラと広域テフラとの層序関係を明らかにし，それら示標テ フラの層序を全国的な第四紀層序の枠組みに組み込むことが必要と考えられていた。

筆者らは，宮城県中部の仙台西部地域と北部の鬼首周辺地域（図 1) に拈いてローカルな示標テフラを

表 1 宮城県中・北部の示標テフラとそれらの噴出年代

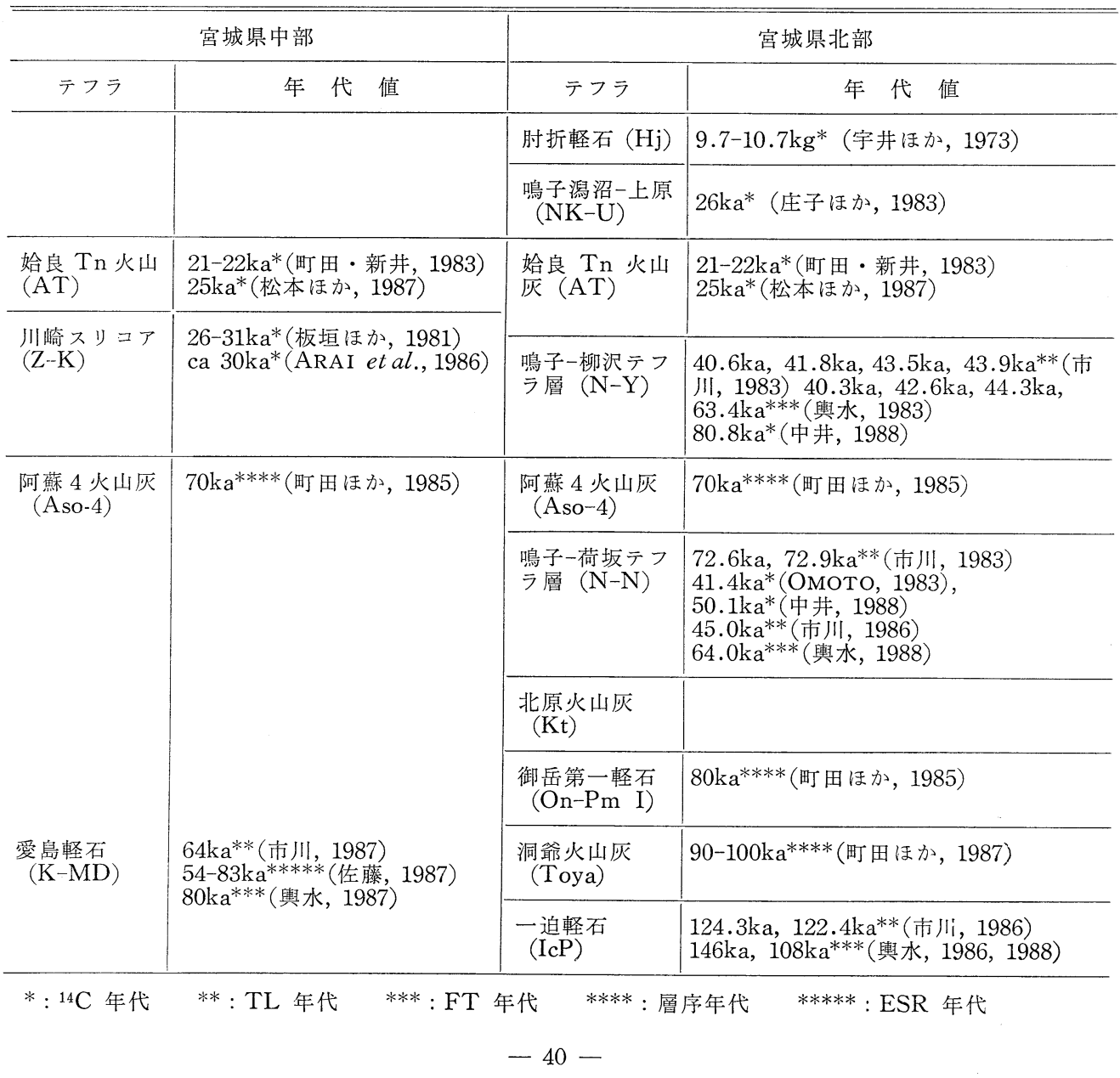




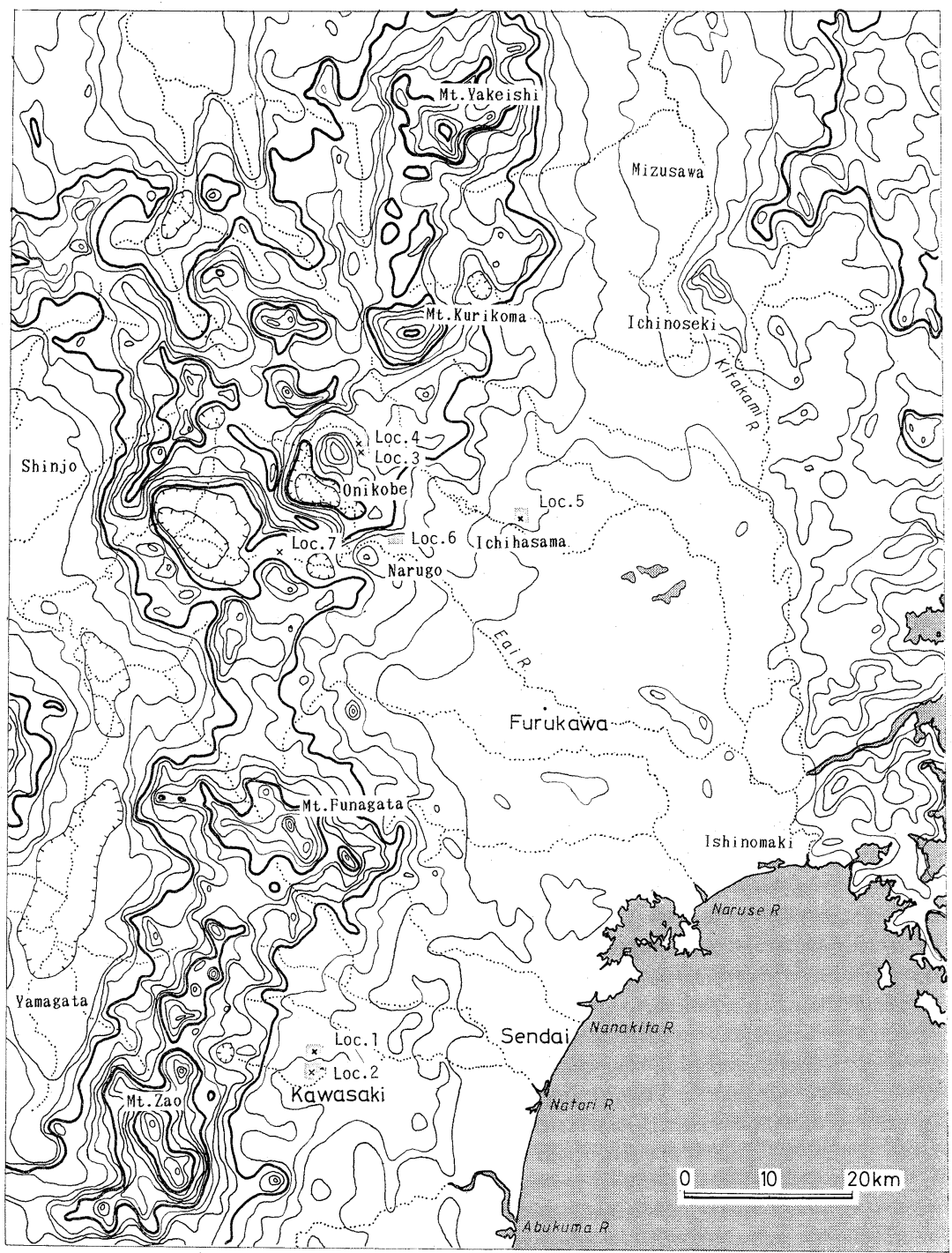

図 1 宮城県中・北部及びその周辺地域の地形概観 $2 \mathrm{~km}$ 以下の埋谷切峰面図等高線間隔は $100 \mathrm{~m}$

挾む地層中に，従来報告のなかった 4 枚の広域テフラを発見した。小論ではまずそれら広域テフラの対比 の根拠とローカルな示標テフラとの層序関係を報告する。次に 広域テフラの層位からみた第四紀編年上の 意義についても言及する。

\section{II. 宮城県中・北部における後期更新世の示標テフラと放射年代值}

宮城県中部の仙台付近においては後期更新世の示標テフラとして，上位より川崎スコリア層，愛島（め でしま) 軽石層が知られている(表 1 )。

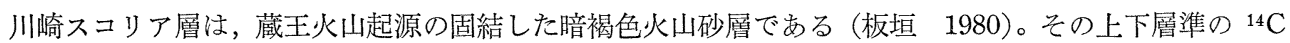


年代が 2 万 6 千年 B.P. および 3 万 1 千年 B.P. であることから(板垣ほか 1981), 約 3 万年 B.P. の降 下年代が推定されている (ARAI et al. 1986)。

愛島軽石層は, 川崎町内に給源火口が位置する安達火山から噴出した降下軽石で, カミングトン閃石を 含む（板垣 1980, 蟹沢 1985)。愛島軽石層は, 仙台付近の台ノ原段丘より上位の段丘を覆い, 青葉山 B

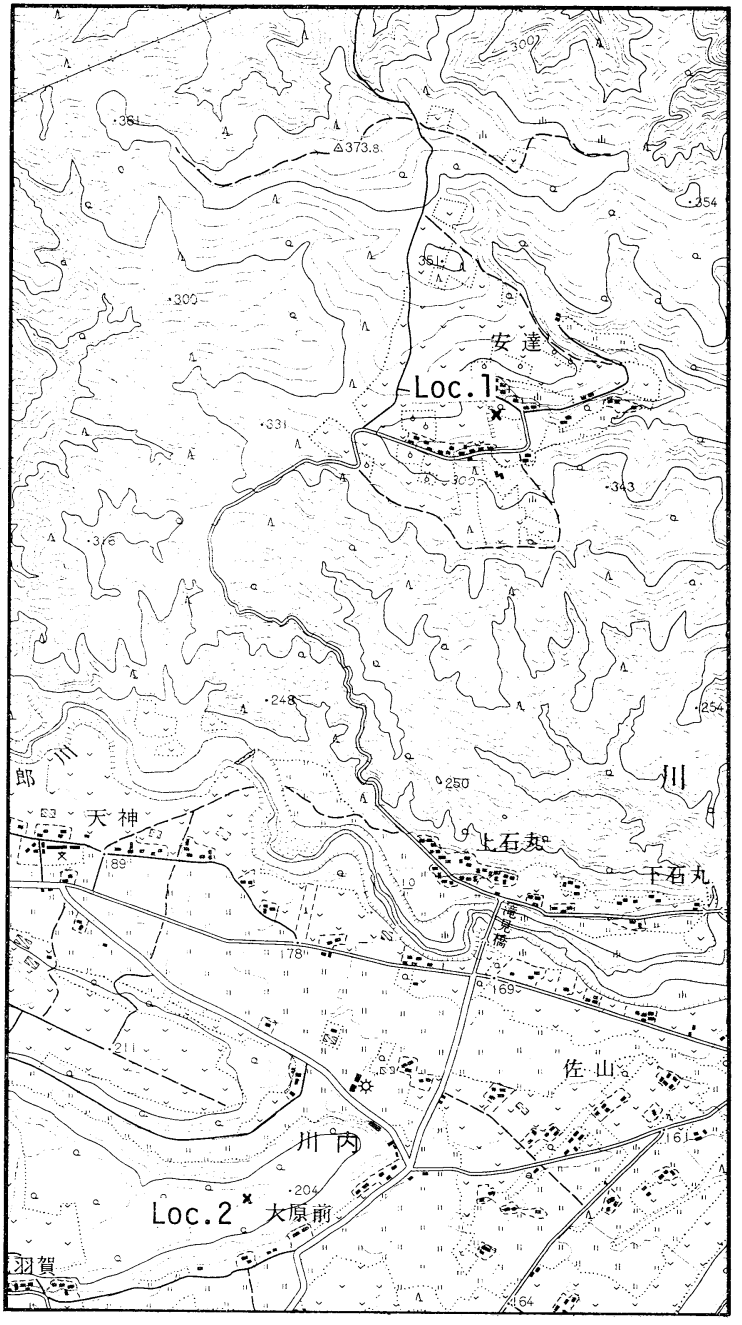

図 2 宮城県中部の広域テフラ産出地点 (Loc. 1,

2) と周辺の地形

使用した地形図は，国土地 理院 発行 $1 / 25,000$ 「陸前川 崎」図幅 (NJ-54-21-7-2)

Loc. 1 は，愛島軽石の給源と考えられている安達火山 の中心付近に位置する。安達火山は, 仙台付近の最高位 礫層である本砂金礫層（中川ほか，1960）の載る丘陵内 に発達した軽石丘である。

Loc. 2 は, 川崎町北に発達する川内段丘（中川ほか, 1960）上に位置する。
遺跡において愛島軽石下位の層準から前期 旧石器の出土が報告されている（須藤ほか 1985)。その年代は，熱ルミネッセンス年代 で 6 万 4 千年 B.P. (市川 1987), ESR 年 代で 5 万 4 千年 B.P. 8 万 3 千年 B.P. (佐藤 1987), フィッション・トラック年 代で 8 万年 B.P. (興水 1987) の噴出年代 が得られているが(表 1 ), 統一的な見解は なかった。

鳴子・鬼首周辺の宮城県北部において は, 後期更新世の示標テフラとして上位よ り肘折軽石層, 鳴子潟沼一上原テフラ層, 鳴子一柳沢テフラ層, 鳴子一荷坂テフラ 層, 北原火山灰層, 一迫軽石層 (早田 1984）が知られている（表 1 )。

肘折軽石層は, 山形県肘折カルデラ起源 とする降下軽石（米地・菊池 1966）で, ${ }^{14} \mathrm{C}$ 年代から約 1 万年 B.P. の降下とされ ている(宇井ほか 1973)。

鳴子潟沼一上原テフラ層は, 鳴子火山潟 沼起源の灰白色細粒火山灰（早田 1989） で, ${ }^{14} \mathrm{C}$ 年代から 2 万 6 千年 B.P. 以前に 降下したとされてきた（庄子ほか 1983）。 鳴子一柳沢テフラ層と鳴子一荷坂テフラ 層は, 鳴子カルデラ起源で火砕流堆積物お よび降下火山灰層・軽石層のユニットから 構成される（早田 1984）。火砕流の堆積 面は江合川流域に広い台地を形成する。馬 場壇 $\mathrm{A}$ 遺跡において鳴子一柳沢テフラ層の 上面や鳴子一柳沢テフラ層と鳴子一荷坂テ フラ層に挾まれた層準に前期旧石器が出土 している(東北歴史資料館・石器文化談話 会 1986)。これら2つのテフラ層に対し て ${ }^{14} \mathrm{C}$ 年代, 熱ルミネッセンス年代, フィ ッション・トラック年代からそれぞれ年代 值が求められてきた(表 1 )。しかし鳴子一 柳沢 テフラ 層で 4 万年 B.P.〜 6 万 3 千年 B.P.(市川 1983, 輿水 1983, 中井 1988), 鳴子一荷坂テフラ層で 4 万 1 千年 B.P. 
7 万 3 千年 B.P.(Omoto 1983, 市川 1983，中井 1988）と同 一テフラに対して得られた年代 值に大きな幅があった。

北原火山灰層と一迫軽石層 は，給源火山がともに不明であ るものの宮城県北西部一帯で認 めることができる灰色の細粒火 山灰および降下軽石層である
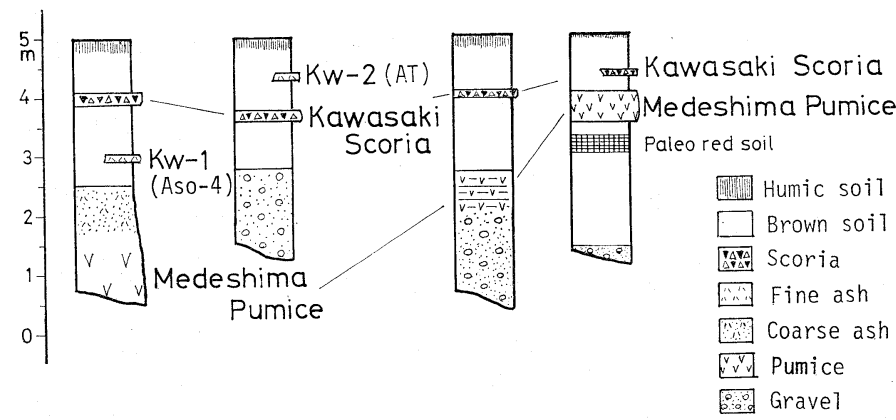

Loc.1

Loc. 2

Dainohara Aobayama

terrace terrace

図 3 宮城県中部のテフラ柱状図

台ノ原段丘拉よび青葉山段丘の柱状図は，それぞれ仙台市鹿野 と仙台市青葉山 B 遺跡に㧍いて観察 石層下位に前期泊石器が出上し ている(東北歴史資料館・石器 文化談話会 1986)。一迫軽石層の 熱ルミネッセンス 年代，フィッション・トラック 年代は，10万 8 千年 B.P. 〜14万 6 千年 B.P. の閒の值を示している (市川 1986，舆水 1986，1988）。

\section{III. 宮城県中・北部に認められる細粒ガラ 不質火山灰}

現地調查に於いては，広域テフラの可能性がある細 粒ガラス質火山灰について岩相とローカルな示標テフ ラとの層序関係を記載した。以下地域ごとに述べる。 宮城県中部

仙台西方約 $15 \mathrm{~km}$ にある川崎町安達の露頭 Loc. 1 （図２）に执いては, 蔵王火山起源の川崎スコリア層 と安達火山を給源とする愛島軽石層に挾をれた褐色風 化火山灰土中に層厚 $4 \mathrm{~cm}$ の橙色 ガラス質細粒火山灰 (Kw 1) がパッチ状に認められる(図 3)。川崎町川内 の Loc. 2 (図 2) においては, 川崎スコリア層上位 の褐色火山灰土中に層厚 $2 \mathrm{~cm}$ の黄色ガラス 質細粒火 山灰 (Kw 2) がパッチ状汇認められる(図 3)。

宮城県北部

鬼首の江合川最上流部（図 4) には，中～細粒砂層 から粘土層で構成される未固結の細粒堆積物が認めら れる。この細粒堆積物は, 従来, 鬼首湖成層 (加藤 島田 1953，小元 1964, Yamada 1972）と呼ばれ てきた細粒堆積物を不整合で覆っている。この細粒堆 積物を切る Loc. 3 に扔いて上下 $2.5 \mathrm{~m}$ の堆積物中に,

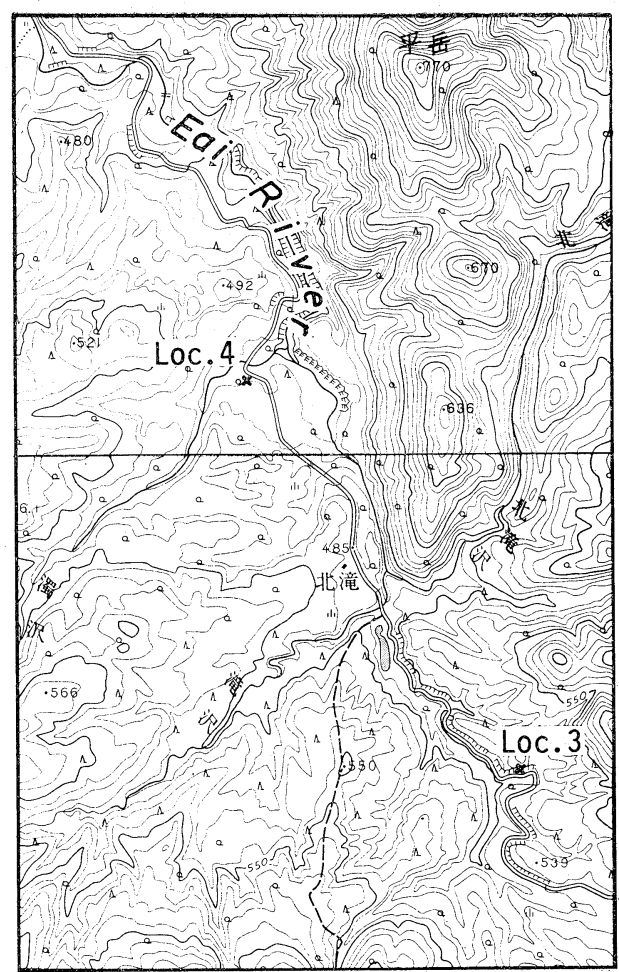

図4 鬼首に㧍ける広域テフラ産出地点 (Loc. 3，4) と周辺の地形 使用した地形図は，国土地理院発行 $1 / 25,000$ 「軍沢」図幅 (NJ-54-20-7-2) 抒よび「鬼首」 図幅 (NJ-54-20-8-1)

4 枚のガラス質火山灰層（上位より Onk 1-1～1-4）が挾まれている（図 5)。Onk 1-1 は層厚 $5 \mathrm{~cm}$ の桃白色火山灰層である。Onk 1-2 は層厚 $4 \mathrm{~cm}$ の灰白色火山灰層で，下部に火山豆石が認められる。火 


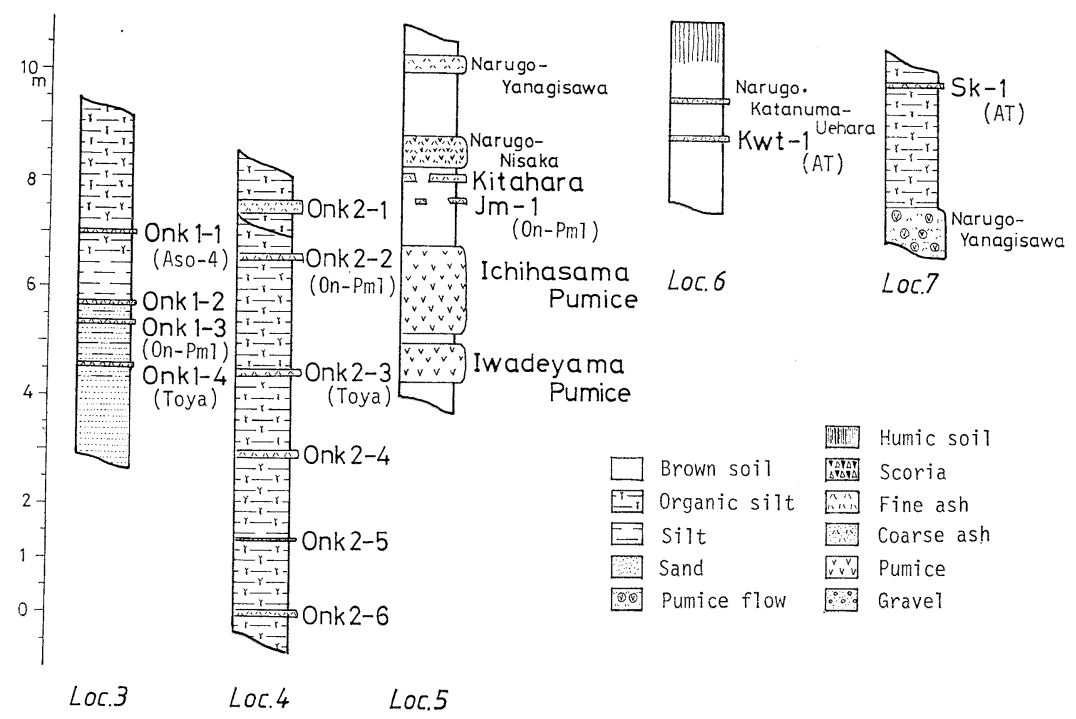

図 5 宮城県北部のテフラ柱状図

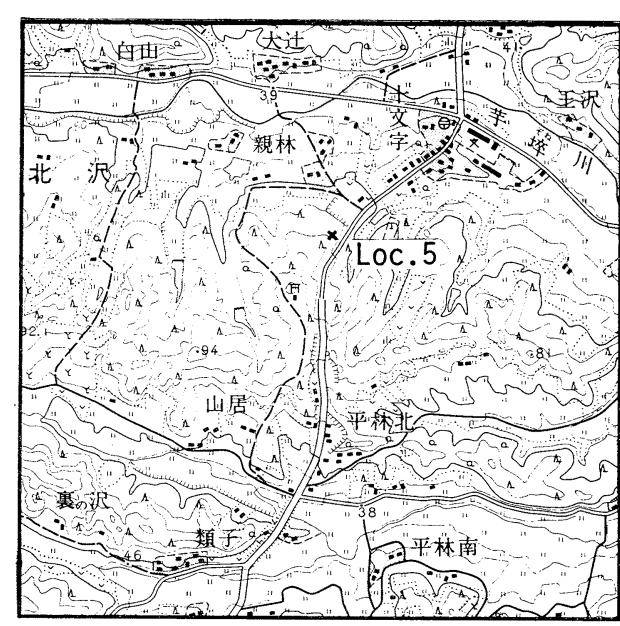

図 6 一迫町十文字における広域テフ ラ産出地点 (Loc. 5) と周辺の 地形

使用した地形図は，国土地理院発行 $1 / 25,000$ 「岩ケ崎」図幅 (NJ-54-20-4-1)

チ状に認められる（図 5, 図6)。

鳴子町・川渡の東北大学付属農場北 (Loc. 6) では鳴子潟沼一上原テフラの下位に細粒ガラス質火山灰 (Kt-1) が認められる（図 5, 図 7 )。なお, 鳴子潟沼一上原テフラの挾まれる褐色火山灰土は黒ボク土 に覆われるが，その黒ボク土直下に，約 1 万年 B.P. に降下した肘折軽石の降灰層準あることが知られて いる（庄子ほか 1983）。

鳴子の西 $7 \mathrm{~km}$ の位置にある宮城・山形県境付近の最上町堺田（Loc. 7 : 図 5, 図 8）では，柳沢火砕
山豆石の最大長径は $8 \mathrm{~mm}$ である。Onk 1-3は層厚 $4 \mathrm{~cm}$ の白色火山灰層, Onk 1-4 は層厚 $8 \mathrm{~cm}$ の白色 火山灰層で，ともに上部に二次堆積層をのせる。この 二次堆積層には周辺に厚く分布する池月テフラ層, 花 山火砕流堆積物 (早田 1988) 起源の火山ガラスを混 じえる。

Loc. 3 から $1.5 \mathrm{~km}$ 下流側の Loc. 4 では, 有機質 な泥質堆積物中に 6 枚のガラス質細粒火山灰層（上位 より Onk 2-1〜Onk 2-6) が認められる（図 5)。 Onk 2-1 は層厚 $22 \mathrm{~cm}$ の淡黄灰色の細粒砂状火山灰層 で，本火山灰層を含む堆積物は，地滑り移動ブロック として下位の層準を覆う。Onk 2-2 は層厚 $3 \mathrm{~cm}$ の青 灰色火山灰層である。Onk 2-3 潧厚 $10 \mathrm{~cm}$ の白色 火山灰層である。Onk 2-4, Onk 2-5 およびOnk 26 はそれぞれ層厚 1 $2 \mathrm{~cm}$ の灰白色火山灰層である。

鬼首から東一約 $10 \mathrm{~km}$ 離れた一迫町十文字付近の Loc. 5 では北原火山灰層と一迫軽石層に挾まれた褐 色火山灰土中に細粒ガラス質火山灰 (Jm-1) がパッ 
流堆積物を不整合に覆う泥炭層中に，層厚 $3 \mathrm{~cm}$ の白色細粒 ガラス 質火山灰層 ( $\mathrm{Sk}$ 1) が認められる。

\section{IV. 細粒ガラス質火山灰の広域 テフラへの対比}

広域テフラは，珪長質マグマに由来する 巨大火砕流やプリニー式噴火などの多量の 本質物質の噴火に起源を持ち，遠隔地にま で達する細粒の 火山ガラスを主体とする (町田・新井 1983)。このため広域テフラ の対比・同定に際して, 火山ガラスの形態 的特徴の記載, 屈折率測定及び主成分分析 は有効な手法となる。本報告ではこれらの 手法を用いて，採取した細粒ガラス質火山 灰の対比・同定を行った。なお，火山ガラ スの屈折率は群馬大学の新井房夫先生にお 願いした。火山ガラスの主成分分析では, 東北大学理学部青木研究室のエネルギー分 散型EPMA(日立X560S・Kevex-Quantex 7000)を使用させていただいた。この EPMA は，標準試料分析や多くの鉱物試 料に対するトータル・ストイキオメトリの

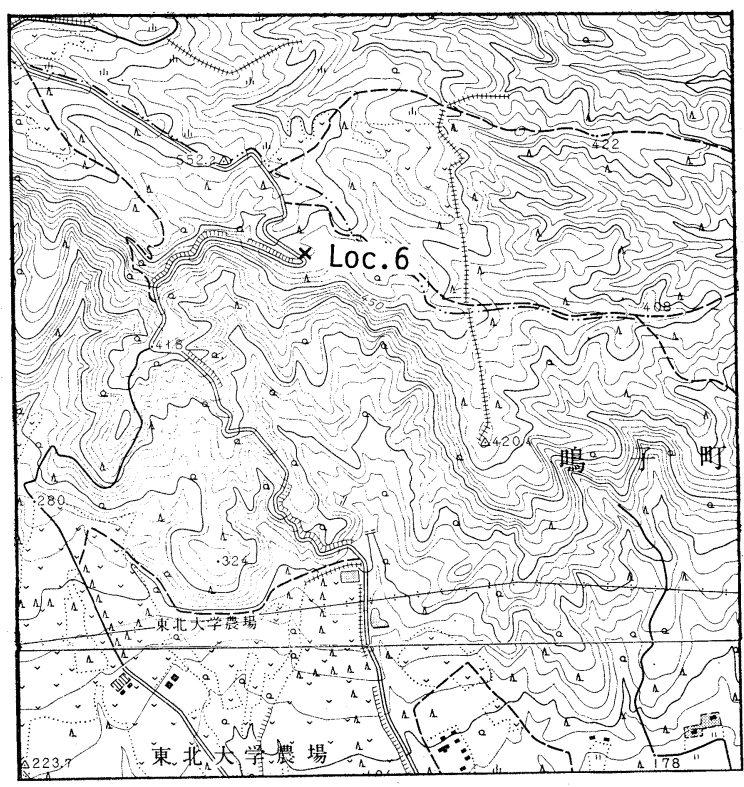

図 7 鳴子町川度における広域テフラの産出 地点 (Loc. 6) と周辺の地形 使用した地形図は, 国土地理院発行 1/25,000「花山 湖」図幅 (NJ-54-20-4-1) および「川度」図幅 (NJ-54-20-4-2) Loc. 6 は，小元 (1966) の三条 面上に位置する。

点検から分析值の信頼性・再現性が確認されている (東北大学理学部岩鉱教室藤巻和宏博士談)。

主成分分析に供した火山ガラスは，火山灰を超音 波洗浄器で水洗いし，風化物を除去したのち粒径 0.088-0.125mm のものについて実体顕微鏡下で直 接分離した。分離した火山ガラスは, エポキシ樹脂 で固定・研磨・炭素被膜の蒸着の後, 加速電圧 20 $\mathrm{KV}$, ビーム電流 $2 \times 10^{-10} \mathrm{~A}$, ビーム径約 $2 \mu \mathrm{m}$ で 1 試料につき 10 粒子ずつ分析した。1 粒子あたりの計 測時間は 400 500 秒である。

上述の細粒ガラス質火山灰について行った岩相記 載, 屈折率測定, 主成分分析の測定・分析結果を表 2 , 表 3 に示した。主成分組成の各分析值は，10粒 子の平均值ですべて無水に換算したものにその標準 偏差とともに記してある。一部の試料を除いて以下 の理由から $\mathrm{MnO}$ 除いた分析結果を示した。なぜ なら, 分析に供した火山ガラス中の $\mathrm{MnO}$ の含有率 は低く (0.1\%以下), その変異係数（山田・庄司 1983）も大きいことから $\mathrm{MnO}$ が対比の鍵となりに

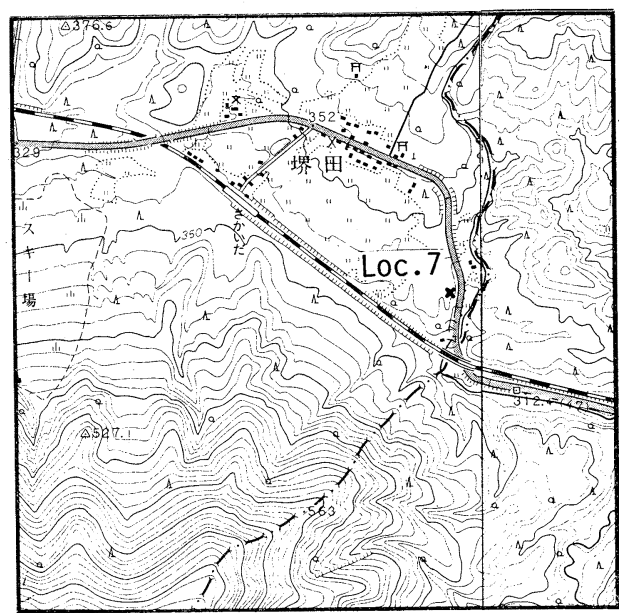

図 8 宮城・山形県境・堺田における広 域テフラの産出地点 (Loc. 7) と 周辺の地形

使用した 地形図は，国土地理 院発行 $1 / 25,000$ 「鳴子」図幅 (NJ-54-20-8-2) および「羽前赤 倉」図幅 (NJ-54-20-8-4) 
表 2 細粒ガラス質火山灰の岩相記載

\begin{tabular}{|c|c|c|c|c|c|}
\hline & 露頭位置 & テフラ & 鉱物組成 & 火山ガラスの特徵 & 屈 折 \\
\hline \multirow{2}{*}{$\begin{array}{l}\text { 中 } \\
\text { 部 }\end{array}$} & $\begin{array}{l}\text { Loc. } 1 \\
\text { (川崎町安達) }\end{array}$ & $\mathrm{Kw}_{\mathrm{w}}-1$ & vitric (ho, mt, opx) & bw 含有色ガラス & $\mathrm{gl}: 1.507-1.510$ \\
\hline & $\begin{array}{l}\text { Loc. } 2 \\
\text { (川崎町川内) }\end{array}$ & $\mathrm{Kw}_{\mathrm{w}}-2$ & vitric & $\mathrm{bw}>\mathrm{pm}$ & $\mathrm{gl}: 1.499-1.501$ \\
\hline \multirow{5}{*}{$\begin{array}{l}\text { 北 } \\
\text { 部 }\end{array}$} & $\begin{array}{l}\text { Loc. } 3 \\
\text { (鳴子町鬼首) }\end{array}$ & $\begin{array}{l}\text { Onk1-1 } \\
\text { Onk1-2 } \\
\text { Onk1-3 } \\
\text { Onk1-4 }\end{array}$ & $\begin{array}{l}\text { vitric (ho, opx, au) } \\
\text { vitric (opx) } \\
\text { vitric ( } \mathrm{bi}>\mathrm{ho}, \mathrm{opx}) \\
\text { vitric }\end{array}$ & $\begin{array}{l}\mathrm{bw} \text { 含有色ガラス } \\
\mathrm{pm} \\
\mathrm{pm} \\
\mathrm{pm}>\mathrm{bw}\end{array}$ & $\begin{array}{l}\text { gl : } 1.509-1.512 \\
\text { gl : } 1.500-1.502 \\
\text { gl : } 1.500-1.503 \\
\text { gl : } 1.496-1.498\end{array}$ \\
\hline & $\begin{array}{l}\text { Loc. } 4 \\
\text { (鳴子町鬼首) }\end{array}$ & $\begin{array}{l}\text { Onk2-1 } \\
\text { Onk2-2 } \\
\text { Onk2-3 } \\
\text { Onk2-4 } \\
\text { Onk2-5 } \\
\text { Onk2-6 }\end{array}$ & $\begin{array}{l}\text { vitric (opx, ho, bi) } \\
\text { vitric (bi> ho, opx) } \\
\text { vitric } \\
\text { vitric } \\
\text { qt, pl (opx) } \\
\text { qt, pl (opx) }\end{array}$ & $\begin{array}{l}\mathrm{pm} \\
\mathrm{pm} \\
\mathrm{pm}<\mathrm{bw} \\
\mathrm{pm} \\
\mathrm{pm} \\
\mathrm{pm}\end{array}$ & $\begin{array}{l}\text { gl : } 1.502-1.505 \\
\text { gl }: 1.500-1.503 \\
\text { gl : } 1.496-1.498 \\
\text { gl }: 1.527-1.530 \\
\text { gl : } 1.505-1.508 \\
\text { gl }: 1.505-1.508\end{array}$ \\
\hline & $\begin{array}{l}\text { Loc. } 5 \\
\text { (一迫町十文字) }\end{array}$ & $\mathrm{Jm}-1$ & vitric (opx, bi) & $\mathrm{pm}$ & $\mathrm{gl}: 1.502-1.504$ \\
\hline & $\begin{array}{l}\text { Loc. } 6 \\
\text { (鳴子町川度) }\end{array}$ & Kwt-1 & vitric (opx, au, mt) & $\mathrm{bw}>\mathrm{pm}$ & $\mathrm{gl}: 1.499-1.501 \quad(1.500)$ \\
\hline & $\begin{array}{l}\text { Loc. } 7 \\
\text { (最上町堺田) }\end{array}$ & Sk-1 & vitric & $\mathrm{bw}>\mathrm{pm}$ & $\mathrm{gl}: 1.499-1.501 \quad(1.500)$ \\
\hline
\end{tabular}

くいからである。さらに，エネルギー分散型 EPMA の特性として，含有率が $0.1 \%$ 以下と低い成分につ いて精度の高い測定には計測時間を長く取る必要があり, 限られた分析機器借用時間内での効率を考慮し たからである。

これらの細粒ガラス質火山灰を対比するため, 宮城県中・北部の示標テフラおよび 後期更新世の広域テ フラ1の岩相記載と主成分組成を表に示した（表 4，5，6，7）。テフラの岩相記載は，新井・町田 (1980), 町田ほか (1984), 町田 (1986), Arai et al. (1986) に従った。主成分組成は筆者らのオリジナ ルなデータで，上記の方法で分析した。表に示した各テフラの主成分組成は，一部のものを除いてそれぞ れ固有の組成を示す（表 $5 ， 7$ )。各成分とも組成が類似する鳴子一柳沢テフラ層と鳴子一荷坂テフラ層拉 よび恵庭- $\mathrm{a}$ 軽石と支忽降下軽石- 1 の 2 組についても, 各テフラの鉱物組成や鉱物の屈折率を比較すれば 同定可能である（表 4，6）。このようにテフラの同定に際して，岩相と主成分組成を組み合わせることが 有効と考え作業を進めた。その結果, 姶良 $\mathrm{Tn}$ 火山灰 (AT), 阿蘇 4 火山灰 (Aso-4), 御岳第 1 軽石 (On-PmI), 洞爺火山灰（Toya）に対比されるテフラを認めることができた。以下各広域テフラに対比さ れる細粒ガラス質火山灰（試料名）と対比の根拠を述べる。

姶良 $\mathrm{Tn}$ 火山灰 (AT)

$\mathrm{Kw}-2, \mathrm{Kwt}-1, \mathrm{Sk}-1$ は, 屈折率が1,499-1.501の薄いバブルウォール型火山ガラスからなる。主成 分組成は $\mathrm{SiO}_{2}$ が77.5 78.0\%, $\mathrm{K}_{2} \mathrm{O}+\mathrm{Na}_{2} \mathrm{O}$ が $7 \%$ と高く, $\mathrm{TiO}_{2}$ が $0.09 \sim 0.11 \%, \mathrm{Al}_{2} \mathrm{O}_{3}$ が $12.91 \sim$ $13.16 \%$ と低い。このためこれらの火山灰は姶良 Tn 火山灰 (AT) に対比される。

阿蘇 4 火山灰 (Aso-4)

$\mathrm{Kw}-1$ およよ゙ Onk 1-1 は, ともに有色のバブルウォール型火山ガラスを含み, 火山ガラスの屈折率は 
表 3 細粒火山灰 (火山ガラス) の主成分組成

\begin{tabular}{|c|c|c|c|c|c|c|c|c|c|c|c|}
\hline テフラ & & $\mathrm{SiO}_{2}$ & $\mathrm{TiO}_{2}$ & $\mathrm{Al}_{2} \mathrm{O}_{3}$ & $\mathrm{FeO}$ & $\mathrm{MnO}$ & $\mathrm{MgO}$ & $\mathrm{CaO}$ & $\mathrm{K}_{2} \mathrm{O}$ & $\mathrm{Na}_{2} \mathrm{O}$ & Total \\
\hline \multirow[t]{2}{*}{$\mathrm{Kw}_{\mathrm{w}}-1$} & M & 72.70 & 0.35 & 15.62 & 1.44 & 0.04 & 0.54 & 1.09 & 4.76 & 3.46 & 100.00 \\
\hline & SD & & 0.02 & 0.17 & 0.01 & 0.01 & 0.03 & 0.03 & 0.04 & 0.32 & \\
\hline \multirow[t]{2}{*}{$\mathrm{Kw}^{-2}$} & $\mathrm{M}$ & 77.27 & & 12.87 & & & 0.47 & 1.09 & 3.42 & 3.75 & 100.00 \\
\hline & $\mathrm{SD}$ & 0.31 & & 0.12 & 0.04 & $\ldots$ & 0.01 & 0.01 & .13 & 0.10 & \\
\hline \multirow[t]{2}{*}{ Onk1-1 } & $\mathrm{M}$ & 71.78 & 0.37 & 15.50 & 1.46 & 0.06 & 0.55 & 1.05 & 4.89 & 4.34 & 100.00 \\
\hline & $\mathrm{SD}$ & & & 0.14 & م & 0.02 & & 0.03 & .09 & 0.18 & \\
\hline \multirow[t]{2}{*}{ Onk1-2 } & $\mathrm{M}$ & 78.36 & 0.08 & 13.17 & 1.12 & $\ldots$ & 0.31 & 1.04 & 1.96 & 3.96 & 100.00 \\
\hline & $\mathrm{SD}$ & 0.22 & 0.01 & 0.08 & 0.05 & $\ldots$ & 06 & 0.13 & .09 & 0.22 & \\
\hline \multirow[t]{2}{*}{ Onk1-3 } & $\mathrm{M}$ & 75.44 & 0.18 & 13.91 & 1.09 & $\cdots$ & 0.57 & 1.32 & 3.82 & 3.67 & 100.00 \\
\hline & $\mathrm{SD}$ & & & & & $\cdots$ & & & .14 & 0.34 & \\
\hline \multirow[t]{2}{*}{ Onk1-4 } & $\mathrm{M}$ & 78.26 & 0.07 & 13.43 & 0.79 & $\ldots$ & 0.28 & 0.40 & 2.97 & 3.79 & 99.99 \\
\hline & SD & 0.53 & 0.03 & 0.06 & 0.04 & $\ldots$ & 0.01 & 0.01 & 0.10 & 0.61 & \\
\hline \multirow[t]{2}{*}{ Onk2-1 } & $\mathrm{M}$ & 75.84 & 0.05 & 14.4 & 0.4 & $\ldots$ & & 66 & 2 & 4.06 & 100.01 \\
\hline & $\mathrm{SD}$ & 0.29 & 0.02 & 0 & .0 & $\ldots$ & 0.05 & 0.03 & 0. & 0.36 & \\
\hline \multirow[t]{2}{*}{ Onk2-2 } & $M$ & 75.14 & 0.12 & 14.32 & 0.89 & $\ldots$ & 0.46 & 1.42 & 3.66 & 3.98 & 99.99 \\
\hline & $\mathrm{SD}$ & 0.45 & 0.02 & 0.30 & 05 & $\ldots$ & 0.02 & 0.28 & .14 & 0.13 & \\
\hline \multirow[t]{2}{*}{ Onk2-3 } & $\mathrm{M}$ & 78.17 & 0.0 & 13.5 & 0.8 & $\ldots$ & 0. & 0 . & 2. & 3.70 & 100.01 \\
\hline & $\mathrm{SD}$ & 0.50 & 0.01 & & 0.0 & $\ldots$ & 0.05 & 0.02 & 0.11 & 0.47 & \\
\hline \multirow[t]{2}{*}{ Onk2-4 } & $\mathrm{M}$ & 70.17 & 0.56 & 15.43 & 3.83 & $\ldots$ & 1.41 & 3.74 & 1.02 & 3.84 & 100.00 \\
\hline & $\mathrm{SD}$ & 0.60 & 0.03 & & 0.13 & $\ldots$ & 0.1 & & & 0.56 & \\
\hline \multirow[t]{2}{*}{ Onk2-5 } & $\mathrm{M}$ & 76.50 & 0.16 & 13.59 & 1.96 & $\ldots$ & 0.6 & 2.00 & 1.25 & 3.91 & 100.01 \\
\hline & $\mathrm{SD}$ & 0.85 & 0.02 & 0.29 & 0.63 & $\ldots$ & 0.29 & 0.36 & 0.08 & 0.20 & \\
\hline \multirow[t]{2}{*}{ Onk2-6 } & $\mathrm{M}$ & 76.78 & 0.15 & 14.03 & 1.70 & $\ldots$ & 0.50 & 2.05 & 1.17 & 3.61 & 99.99 \\
\hline & $\mathrm{SD}$ & 0.29 & 0.02 & 0.03 & 0.15 & $\ldots$ & 0.06 & 0.07 & 0.05 & 0.51 & \\
\hline \multirow[t]{2}{*}{$\mathrm{Jm}-1$} & $\mathrm{M}$ & 75.54 & 0.20 & 13.95 & 1.11 & $\ldots$ & 0.57 & 1.36 & 3.78 & 3.49 & 100.00 \\
\hline & $\mathrm{SD}$ & 0.17 & 0.02 & 0.22 & 0.02 & $\ldots$ & 0.05 & 0.03 & 0.07 & 0.32 & \\
\hline \multirow[t]{2}{*}{ Kwt-1 } & $\mathrm{M}$ & 77.24 & 0.10 & 12.91 & 1.13 & & 0.36 & 1.02 & 3.58 & 3.66 & 100.00 \\
\hline & $\mathrm{SD}$ & 0.29 & 0.02 & 0.11 & 0.08 & $\ldots$ & 0.04 & 0.03 & 0.09 & 0.28 & \\
\hline \multirow[t]{2}{*}{ SK-1 } & M & 78.26 & 0.11 & 13.12 & & 0.03 & & 1.12 & 3.32 & 2.47 & 99.99 \\
\hline & $\mathrm{SD}$ & 0.34 & 0.02 & 0.13 & 0.04 & 0.01 & 0.05 & 0.02 & 0.21 & 0.23 & \\
\hline
\end{tabular}

1 試料あたり 10 粒子の平均值と標準偏差 $\mathrm{M}$ : 平均值 $\mathrm{SD}$ : 標準偏差

1.509-1.512 と非常に高い。主成分組成は， $\mathrm{SiO}_{2}$ が72\%前後と低い。これに対し $\mathrm{TiO}_{2}$ が $0.35 \sim 0.37 \%$ ， $\mathrm{Al}_{2} \mathrm{O}_{3}$ が $15.5 \sim 15.62 \% ， \mathrm{~K}_{2} \mathrm{O}+\mathrm{Na}_{2} \mathrm{O}$ が 9 \%以上と高い。特に $\mathrm{K}_{2} \mathrm{O}$ が $4.8 \%$ 前後と分析試料中最も高 い。以上の特徴から, これらは阿蘇 4 火山灰 (Aso-4) に対比される。

\section{御岳第 1 軽石 (On-PmI)}

Onk 1-3, Onk 2-2, Jm-1 は, 黒雲母, 角閃石および繊維状軽石型火山ガラスを含む火山灰である。 火山ガラスの屈折率は1.502-1.504である。主成分組成は, $\mathrm{SiO}_{2}$ が75\%強, $\mathrm{MgO}$ と $\mathrm{CaO}$ がそれぞれ $0.5 \%$ おび $1.4 \%$ 前後と中間的な值を示すことに対し, $\mathrm{Al}_{2} \mathrm{O}_{3}$ が $14 \%$ 前後, $\mathrm{K}_{2} \mathrm{O}+\mathrm{Na}_{2} \mathrm{O}$ が $7 \sim 7.5 \%$ 前後 と高めである。以上の特徵から，これらは御岳第 1 軽石 (On-PmI) に対比される。

洞爺火山灰 (Toya)

Onk 1-4, Onk 2-3 は，屈折率1.496-1.498の繊維束状の軽石型および 少量のバブルウォール型火山 
表 4 宮城県中・北部の示標テフラの岩相記載

\begin{tabular}{|c|c|c|c|}
\hline 示標テフラ & 鉱物組成 & $\begin{array}{l}\text { 火山ガラ } \\
\text { スの形態 }\end{array}$ & 折 \\
\hline $\begin{array}{l}\text { 川崎スコリア (Z-K) } \\
\text { 愛島軽石 (K-MD) }\end{array}$ & $\begin{array}{l}\text { opx }>\mathrm{cpx} \\
\text { cum ; qt }\end{array}$ & $\mathrm{pm}$ & $\begin{array}{l}\text { opx }(\gamma): 1.700-1.704 \\
\text { gl }: 1.504-1.507(1.505-1.506) \\
\text { cum }\left(\mathrm{n}_{2}\right): 1.660-1.665\end{array}$ \\
\hline $\begin{array}{r}\text { 鳴子潟沼-上原テフラ } \\
(\mathrm{NK}-\mathrm{U})\end{array}$ & $\mathrm{opx}>\mathrm{cpx}=\mathrm{mt}$ & $\mathrm{pm}$ & $\begin{array}{l}\mathrm{gl}: 1.492-1.500 \\
\mathrm{opx}(\gamma): 1.711-1.715\end{array}$ \\
\hline 时折軽石 $(\mathrm{Hj})$ & $o p x>$ ho ; qt & $\mathrm{pm}$ & $\begin{array}{l}\mathrm{g} 1: 1.499-1.501 \\
\text { opx }(\gamma): 1.712-1.714 \\
\text { ho }\left(\mathrm{n}_{2}\right): 1.668-1.671\end{array}$ \\
\hline $\begin{array}{l}\text { 鳴子-柳沢テフラ } \\
\qquad(\mathrm{N}-\mathrm{Y})\end{array}$ & opx $>$ ho, mt (bi, cpx); qt & $\mathrm{pm}>\mathrm{bw}$ & $\begin{array}{l}\mathrm{g} 1: 1.501-1.503 \\
\text { opx }(\gamma): 1.717-1.722(1.719) \\
\text { ho }\left(\mathrm{n}_{2}\right): 1.673-1.676\end{array}$ \\
\hline $\begin{array}{l}\text { 鳴子-荷坂テフラ } \\
\qquad(\mathrm{N}-\mathrm{N})\end{array}$ & $o p x>m t: q t$ & $\mathrm{pm}$ & $\begin{array}{l}\mathrm{gl}: 1.500-1.502(1.501) \\
\mathrm{opx}(\gamma): 1.724-1.728\end{array}$ \\
\hline 北原火山灰 $(\mathrm{Kt})$ & poor $(\mathrm{mt}>\mathrm{opx}$, cum $)$ & $\mathrm{pm}$ & $\mathrm{gl}: 1.499-1.502$ \\
\hline 一迫軽石 (IcP) & $\mathrm{opx}>\mathrm{mt}$ & $\mathrm{pm}$ & opx $(\gamma): 1.728-1.733$ \\
\hline
\end{tabular}

ARAI et al. (1986) による

表 5 宮城県中・北部の示標テフラ（火山ガラス）主成分組成

\begin{tabular}{|c|c|c|c|c|c|c|c|c|c|c|c|c|}
\hline 示標テフラ & 試料採取地 & & $\mathrm{SiO}_{2}$ & $\mathrm{TiO}_{2}$ & $\mathrm{Al}_{2} \mathrm{O}_{3}$ & $\mathrm{FeO}$ & $\mathrm{MnO}$ & $\mathrm{MgO}$ & $\mathrm{CaO}$ & $\mathrm{K}_{2} \mathrm{O}$ & $\mathrm{Na}_{2} \mathrm{O}$ & Total \\
\hline \multirow{2}{*}{$\begin{array}{l}\text { 愛島軽石 } \\
\text { (K-MD) }\end{array}$} & \multirow[t]{2}{*}{ 川崎町安達 } & M & 76.94 & 0.12 & 14.47 & 1.01 & & 0.61 & 1.70 & 1.27 & 3.88 & \multirow[t]{2}{*}{100.00} \\
\hline & & SD & 0.53 & 0.02 & 0.44 & 0.03 & & 0.06 & 0.07 & 0.04 & 0.22 & \\
\hline \multirow{2}{*}{$\begin{array}{r}\text { 时折軽石 } \\
(\mathrm{Hj})\end{array}$} & \multirow[t]{2}{*}{ 宮崎町台の原 } & $\mathrm{M}$ & 77.79 & 0.16 & 12.76 & 1.05 & & 0.44 & 1.09 & 3.10 & 3.61 & \multirow[t]{2}{*}{100.00} \\
\hline & & $\mathrm{SD}$ & 0.77 & 0.05 & 0.38 & 0.01 & & 0.20 & 0.11 & 0.12 & 0.85 & \\
\hline \multirow{2}{*}{$\begin{array}{l}\text { 鳴子潟沼一上原 } \\
\text { テフラ }(\mathrm{NK}-\mathrm{U})\end{array}$} & \multirow[t]{2}{*}{ 鳴子町上ノ原 } & $\mathrm{M}$ & 77.98 & 0.22 & 12.28 & 1.22 & $\cdots$ & 1.01 & 1.59 & 1.47 & 4.23 & \multirow[t]{2}{*}{100.00} \\
\hline & & $\mathrm{SD}$ & 0.30 & 0.01 & 0.12 & 0.04 & $\cdots$ & 0.01 & 0.01 & 0.10 & 0.13 & \\
\hline \multirow{2}{*}{$\begin{array}{l}\text { 鳴子-柳沢テ } \\
\text { フラ }(\mathrm{N}-\mathrm{Y})\end{array}$} & \multirow[t]{2}{*}{ 岩出山町安沢 } & M & 78.11 & 0.17 & 12.98 & 1.28 & $\cdots$ & 0.43 & 1.52 & 1.93 & 3.57 & \multirow[t]{2}{*}{99.99} \\
\hline & & $\mathrm{SD}$ & 0.40 & 0.03 & 0.41 & 0.07 & & 0.08 & 0.05 & 0.04 & 0.12 & \\
\hline \multirow{2}{*}{$\begin{array}{l}\text { 鳴子-荷坂テ } \\
\text { フラ }(\mathrm{N}-\mathrm{N})\end{array}$} & \multirow[t]{2}{*}{ 岩出山町安沢 } & $\mathrm{M}$ & 78.01 & 0.12 & 12.93 & 1.29 & $\cdots$ & 37.0 & 1.28 & 1.88 & 4.12 & \multirow[t]{2}{*}{100.00} \\
\hline & & $\mathrm{SD}$ & 0.33 & 0.01 & 0.15 & 0.02 & & 0.03 & 0.03 & 0.04 & 0.34 & \\
\hline \multirow{2}{*}{$\begin{array}{r}\text { 北原火山灰 } \\
(\mathrm{Kt})\end{array}$} & \multirow[t]{2}{*}{ 一迫町十文字 } & M & 77.61 & 0.07 & 13.37 & 0.61 & $\cdots$ & 0.32 & 0.70 & 3.89 & 3.43 & \multirow[t]{2}{*}{100.00} \\
\hline & & $\mathrm{SD}$ & 0.32 & 0.02 & 0.14 & 0.03 & & 0.05 & 0.03 & 0.05 & 0.33 & \\
\hline \multirow{2}{*}{$\begin{array}{l}\text { 一迫軽石 } \\
\text { (IcP) }\end{array}$} & \multirow[t]{2}{*}{ 一迫町十文 } & M & 76.99 & 0.15 & 13.07 & 1.93 & & 0.53 & 1.86 & 1.21 & 4.26 & \multirow[t]{2}{*}{100.00} \\
\hline & & $\mathrm{SD}$ & 0.41 & 0.02 & 0.15 & 0.05 & & 0.07 & 0.04 & 0.02 & 0.40 & \\
\hline
\end{tabular}

1 試料あたり 10 粒子の平均值と標準偏差 $\mathrm{M}$ : 平均值 $\mathrm{SD}$ : 標準偏差

ガラスを含む。主成分組成は, $\mathrm{SiO}_{2}$ が $78 \%$ と高く, $\mathrm{TiO}_{2}$ が $0.06 \%, \mathrm{MgO}$ が $0.2 \%, \mathrm{FeO}$ と $\mathrm{CaO}$ が 1 \%以下と他の炊灰に比べ低い。2.9\%程度の $\mathrm{K}_{2} \mathrm{O}$ に比べ $\mathrm{Na}_{2} \mathrm{O}$ が $3.7 \%$ 強と高い。以上の特徴からこれ らは洞爺火山灰 (Toya) に対比される。

なお, Onk 1-2 は灭山豆石を含むことから給源が近いローカルなテフラと予想された。火山ガラスの主 成分組成では, $\mathrm{SiO}_{2}$ が $78 \%$ と高く, $\mathrm{K}_{2} \mathrm{O}$ が $2 \%$ 以下と低いことから鳴子一柳沢テフラ層あるいは鳴子一荷 
表 6 広域テフラの岩相記載

\begin{tabular}{|c|c|c|c|}
\hline 広域テフラ & 鉱物組成 & $\begin{array}{l}\text { 火山ガラ } \\
\text { スの形態 }\end{array}$ & 屈 折 \\
\hline 十和田 $\mathrm{a}$ 火山灰 (To-a) & $\mathrm{pl} ; \mathrm{opx} ; \mathrm{cpx}$ & $\mathrm{pm}>>\mathrm{bw}$ & $\begin{array}{l}\mathrm{gl}: 1.496-1.504 \\
\mathrm{opx}(\gamma): 1.706-1.708\end{array}$ \\
\hline $\begin{array}{l}\text { 十和田-中掫火山灰 } \\
(\mathrm{To}-\mathrm{Cu})\end{array}$ & $o p x>c p x$ & $\mathrm{pm}$ & $\begin{array}{l}\mathrm{gl}: 1.501-1.512 \\
\mathrm{opx}: 1.705-1.708(1.707)\end{array}$ \\
\hline $\begin{aligned} \text { 鬼界ーアカホヤ火山灰 } \\
(\mathrm{K}-\mathrm{Ah})\end{aligned}$ & $\mathrm{pl}$; opx, cpx, (ho, qt) & $\mathrm{bw}>\mathrm{pm}$ & $\begin{array}{l}\mathrm{g} 1: 1.508-1.514 \\
\mathrm{opx}(\gamma): 1.709-1.712\end{array}$ \\
\hline 恵庭- $a$ 軽石（En-a） & opx, cpx & $\mathrm{pm}$ & $\begin{array}{l}\mathrm{gl}: 1.496-1.500 \\
\mathrm{opx}: 1.710-1.715(1.713)\end{array}$ \\
\hline 姶良-Tn 火山灰 $(\mathrm{AT})$ & pl ; opi, cpx, (ho, qu) & $\mathrm{bw}>\mathrm{pm}$ & $\begin{array}{l}\text { gl }: 1.498-1.501 \\
\text { opx }(\gamma): 1.728-1.734\end{array}$ \\
\hline 支忽降下軽石 1 (Spfa1) & $o p x>c p x$, ho (ol) & $\mathrm{pm}$ & $\begin{array}{l}\text { gl : } 1.501-1.505 \\
\text { opx : } 1.729-1.735(1.715-1.724) \\
\text { ho }: 1.688-1.691\end{array}$ \\
\hline 大山一倉吉軽石 (DKP) & $\mathrm{pl}$; ho, opx, bi & $\mathrm{pm}$ & opx $(\gamma): 1.702-1.708$ \\
\hline 阿蘇 4 火山灰（Aso-4） & $\mathrm{pl}$; ho, opx, cpx & $\mathrm{bw}>\mathrm{pm}$ & $\begin{array}{l}\mathrm{gl}: 1.506-1.514 \\
\mathrm{opx}(\gamma): 1.699-1.701 \\
\text { ho }\left(\mathrm{n}_{2}\right): 1.685-1.691\end{array}$ \\
\hline 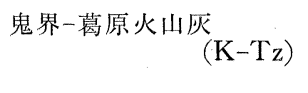 & $\mathrm{pl}, \mathrm{qt} ; \mathrm{opx}, \mathrm{cpx}$ & $\mathrm{bw}>\mathrm{pm}$ & $\begin{array}{l}\mathrm{gl}: 1.496-1.500 \\
\mathrm{opx}(\gamma): 1.705-1.709\end{array}$ \\
\hline $\begin{aligned} \text { 御岳第 } 1 \text { 軽石 } & \text { (On-Pm I) } \\
& \text { (On-P }\end{aligned}$ & ho, bi, (opx) (Rhyoritic) & $\mathrm{pm}$ & $\begin{array}{l}\text { gl : } 1.501-1.503 \\
\text { opx }(\gamma): 1.706-1.711 \quad(1.708) \\
\text { ho }\left(\mathrm{n}_{2}\right): 1.681-1.690\end{array}$ \\
\hline 阿多火山灰（Ata） & $\mathrm{pl} ;$ opx, cpx & $\mathrm{bw}>\mathrm{pm}$ & $\begin{array}{l}\mathrm{gl}: 1.508-1.513 \\
\mathrm{opx}(\gamma): 1.704-1.708\end{array}$ \\
\hline 洞爺火山灰（Toya） & $\mathrm{pl}, \mathrm{qt} ; \mathrm{opx}$ & $\mathrm{pm}>\mathrm{bw}$ & $\begin{array}{l}\mathrm{gl}: 1.494-1.497 \\
\mathrm{opx}(\gamma): 1.756-1.761\end{array}$ \\
\hline 阿蘇 3 火灰 (Aso-3) & $\mathrm{pl}, \mathrm{cpx}, \mathrm{opx}$ & $\mathrm{pm}, \mathrm{bw}$ & $\mathrm{gl}: 1.516-1.518$ \\
\hline
\end{tabular}

新井・町田（1980），町田ほか（1984），町田（1986）および ARAI et al. (1986) による

坂テフラ層の可能性が考えられた。しかし Onk 1-2 は，角閃石を含まないことおよび斜方輝石の屈折率 から鳴子一荷坂テフラ層に対比された。Onk 2-1, Onk 2-4に対比されるテフラは見いだせなかった。 Onk 2-5，6は，化学組成からいずれも一迫軽石層に一致するが，上位の Onk 2-5 は再堆積物質と考え られる。

\section{V. 宮城県中・北部に認められる広域テフラの層位と第四紀後期編年上の意義}

以上のように後期更新世の広域テフラに対比された各細粒ガラス質火山灰について, その産出層位をま とめれば以下のようになる（図 9)。

姶良 $\mathrm{Tn}$ 火山灰 (AT) は, 宮城県中部で川崎スコリア層の上位に, 同北部で鳴子潟沼一上原テフラ層 の下位 ${ }^{2}$ ，鳴子一柳沢テフラ層の上位に挾在する（図 9 )。

阿蘇 4 火山灰 (Aso-4) は, 宮城県中部で川崎スコリア層の下位, 愛島軽石層の上位に挾まれ ${ }^{3}$, 同北部 では鳴子一柳沢テフラ層の下位, 鳴子一荷坂テフラ層の上位に認められる（図 9 )。鳴子一荷坂テフラ層の 
表 7 広域テフラ (火山ガラス) の主成分組成

\begin{tabular}{|c|c|c|c|c|c|c|c|c|c|c|c|c|}
\hline 広域テフラ & 試料: & & $\mathrm{SiO}_{2}$ & $\mathrm{TiO}_{2}$ & $\mathrm{Al}_{2} \mathrm{O}_{3}$ & $\mathrm{FeO}$ & $\mathrm{MnO}$ & $\mathrm{MgO}$ & $\mathrm{CaO}$ & $\mathrm{K}_{2} \mathrm{O}$ & $\mathrm{Na}_{2} \mathrm{O}$ & Total \\
\hline \multirow{2}{*}{$\begin{array}{r}\text { 十和田 } \mathrm{a} \text { 火山灰 } \\
\left(\mathrm{To}^{-} \mathrm{a}\right)\end{array}$} & \multirow{2}{*}{$\begin{array}{r}\text { 十和田湖町 } \\
\text { 睡蓮沼 }\end{array}$} & M & & & & & & & 2.14 & 1.41 & 4.30 & \multirow[t]{2}{*}{100.01} \\
\hline & & SD & & 0.03 & 0.05 & 0.04 & & 0.04 & 0.06 & 0.02 & 0.30 & \\
\hline \multirow{2}{*}{$\begin{array}{l}\text { 十和田一中掫火 } \\
\text { 山灰 }\left(\mathrm{To}^{-\mathrm{Cu}}\right)\end{array}$} & \multirow{2}{*}{$\begin{array}{c}\text { 十和田湖町 } \\
\text { 宇輥部 }\end{array}$} & M & 74.98 & 0.40 & 14.11 & 2.31 & $\ldots$ & 0.90 & 2.79 & 1.32 & 3.40 & \multirow[t]{2}{*}{100.01} \\
\hline & & SD & 0.43 & 0.03 & 0.15 & 0.13 & $\ldots$ & 0.08 & 0.14 & 0.04 & 0.44 & \\
\hline \multirow{2}{*}{$\begin{array}{l}\text { 鬼界ーアカホヤ } \\
\text { 火山灰 (K-Ah) }\end{array}$} & \multirow{2}{*}{$\begin{array}{c}\text { 西之表市 } \\
\text { 島間 }\end{array}$} & $\mathrm{M}$ & 74.88 & 0.51 & 12.98 & 2.46 & $\cdots$ & 0.49 & 2.04 & 2.77 & 3.87 & \multirow[t]{2}{*}{99.99} \\
\hline & & SD & .25 & 0.02 & 0.16 & 0.06 & 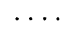 & & & & & \\
\hline \multirow{2}{*}{$\begin{array}{r}\text { 恵庭- } \mathrm{a} \text { 軽石 } \\
\qquad(\mathrm{En}-\mathrm{a})\end{array}$} & \multirow[t]{2}{*}{ 日高町三岡 } & $\mathrm{M}$ & & 0.11 & & & & & & & & \multirow[t]{2}{*}{99.99} \\
\hline & & $\mathrm{SD}$ & & & & & & & & 0.07 & 0.26 & \\
\hline \multirow{2}{*}{$\begin{array}{r}\text { 姶良-Tn 火山灰 } \\
(\mathrm{AT})\end{array}$} & \multirow[t]{2}{*}{ 入戸火砕流 } & M & & 0.10 & 12.98 & 1.20 & 0.05 & 0.34 & 1.12 & 3.43 & 3.38 & \multirow[t]{2}{*}{100.00} \\
\hline & & $\mathrm{SD}$ & & 0.02 & 0.14 & 0.03 & 0.02 & 0.04 & 0.02 & 0.08 & 0.23 & \\
\hline \multirow{2}{*}{$\begin{array}{r}\text { 支忽降下軽石 } \\
\text { (Spfa 1) }\end{array}$} & \multirow[t]{2}{*}{ 門別町富川 } & $\mathrm{M}$ & 77.52 & 0.15 & 13.08 & 1.38 & $\cdots$ & 0.36 & 1.41 & 2.57 & 3.53 & \multirow[t]{2}{*}{100.00} \\
\hline & & SD & 0.29 & 0.02 & 0.09 & 0.02 & 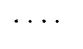 & 0.03 & 0.03 & 0.06 & 0.28 & \\
\hline \multirow{2}{*}{$\begin{array}{r}\text { 阿蘇 } 4 \text { 火山灰 } \\
\text { (Aso-4) }\end{array}$} & \multirow[t]{2}{*}{ 竹田市戸上 } & $\mathrm{M}$ & 71.71 & 0.38 & 15.51 & 1.44 & 0.05 & 0.54 & 1.04 & 5.02 & & \multirow[t]{2}{*}{100.00} \\
\hline & & $\mathrm{SD}$ & 0.16 & 0.02 & 0.15 & 0.02 & & & & & & \\
\hline \multirow{2}{*}{$\begin{array}{l}\text { 鬼界-葛原 } \\
\text { 火山灰 }(\mathrm{K}-\mathrm{T} z)\end{array}$} & \multirow[t]{2}{*}{ 国分市 } & $\mathrm{M}$ & 79.37 & 0.17 & 12.82 & 0.96 & & 0.50 & 1.04 & 3.03 & 2.11 & \multirow[t]{2}{*}{100.00} \\
\hline & & SD & 0.26 & 0.03 & & .03 & & & & 0.04 & 0.30 & \\
\hline \multirow{2}{*}{$\begin{array}{l}\text { 御岳第 } 1 \text { 軽石 } \\
\text { (On-Pm I) }\end{array}$} & \multirow[t]{2}{*}{ 小山町生土 } & $\mathrm{M}$ & 75.34 & 0.13 & 14.61 & 0.91 & & 0.52 & 1.56 & 3.46 & 3.48 & \multirow[t]{2}{*}{100.01} \\
\hline & & SD & 0.90 & 0.02 & 0.22 & 0.03 & & 0.10 & 0.03 & 0.15 & 0.79 & \\
\hline \multirow{2}{*}{$\begin{array}{r}\text { 阿多火山灰 } \\
\text { (Ata) }\end{array}$} & \multirow[t]{2}{*}{ 国分市 } & $\mathrm{M}$ & 73.96 & 0.40 & 13.84 & 2.06 & & 0.70 & 1.83 & 3.16 & 4.09 & \multirow[t]{2}{*}{99.99} \\
\hline & & SD & 0.18 & 0.03 & 0.12 & 0.06 & $\ldots$ & 0.10 & 0.06 & 0.20 & 0.05 & \\
\hline & 江差町砂川 & $\mathrm{M}$ & 78.10 & 0.07 & 13.47 & 0.89 & 0.08 & 0.22 & 0.37 & 2.95 & 3.84 & 99.99 \\
\hline & & SD & 0.24 & 0.02 & 0.10 & 0.22 & 0.03 & 0.07 & 0.03 & 0.18 & 0.28 & \\
\hline 阿真 & , & M & 69.88 & 0.49 & 15.72 & 2.04 & $\cdots$ & 0.77 & 1.66 & 5.23 & 4.22 & 100.01 \\
\hline & & $\mathrm{SD}$ & 0.19 & 0.02 & 0.13 & 0.10 & $\ldots$ & 0.10 & 0.06 & 0.04 & 0.13 & \\
\hline
\end{tabular}

1 試料あたり 10 粒子の平均值と標準偏差 $\mathrm{M}$ ：平均值 $\mathrm{SD}$ : 標準偏差

直下には北原火山灰層があるが，さらにその下位に御岳第 1 軽石 $(\mathrm{On}-\mathrm{PmI})$ が認められる4) (図 9$) 。$

洞爺火山灰 (Toya) は, 御岳第 1 軽石 (On-PmI) の下位, 一迫軽石層の上位 ${ }^{5}$ 任認められる (図 9 )。

このように本研究において, 宮城県に分布する示標テフラと広域テフラとの層序関係を明らかにした結 果, 宮城県の示標テフラの層序およびそれに基づく旧石器産出層位（東北歴史資料館・石器文化談話会 1986）を全国的な第四紀層序の枠組みに組み込むことができた。特に鬼首において，On-PmI と Toya と の間に明確な上下関係を確認できたことは，東北日本北部の重要な示標テフラである Toya の層位を，南 関東における後期更新世広域テフラ層序に組み込んだ点で意義がある。同時にこの成果は，これまで Aso - 4 および Toya と海成面・段丘構成層との層位関係から組み立てられてきた東北日本北部における後期 更新世海成面編年（宮内 1988）をより確かなものとする。すなわち 東北地方北部沿岸の垂直隆起量の大 きな地域において, 最終間水期極相期海成段丘 (12.5万年 B.P. 頃形成) の下位に発達する海成面（たとえ ば能代平野の畑谷 II 面，八戸付近の多賀台面）は，Toya に風成で覆われ，その下位の海成面が Aso-4 4 で 風成で覆われることから10万年前頃6)の離水と考えられていた(八木・宮内 1986 ，宮内 1988)。南関東に おいて既に明らかにされているとおり On-PmI は，8 万年前頃離水した小原台面構成層の最上部に挾まれ る（町田・鈴木 1971，町田ほか 1985)。従って On-PmI の下位に Toya があることは，隆起地域にお いて Toya を風成でのせる最も下位の海成面が，12.5万年 B.P. (下末吉海進) 以降 8 万年 B.P. (小原台 

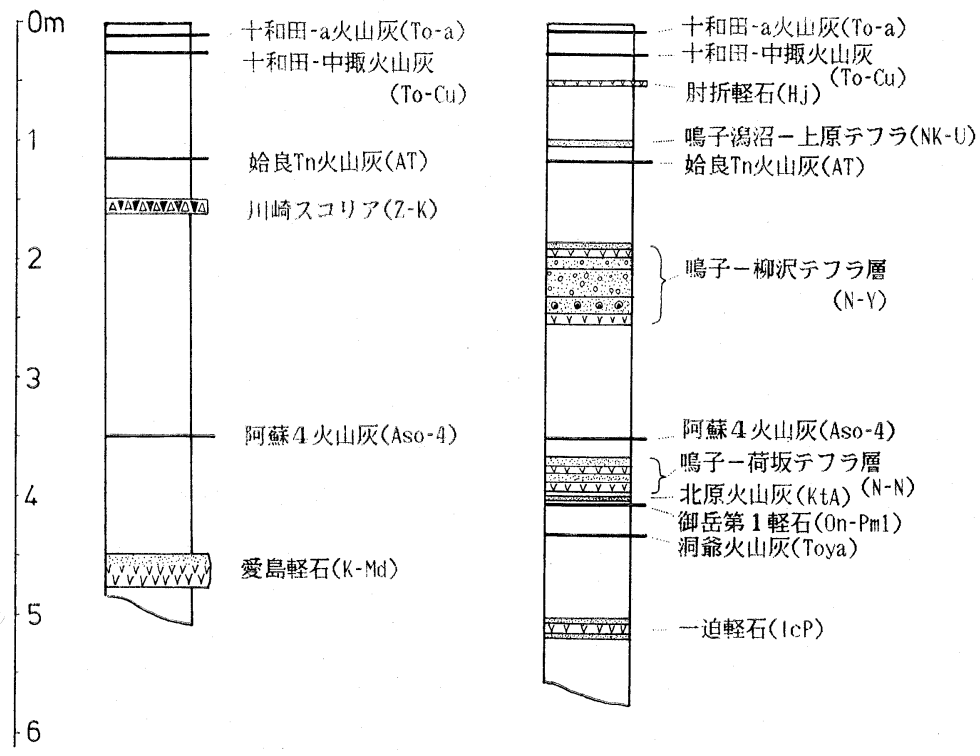

図 9 宮城県中・北部のテフラ総合柱状図

海進）以前に離水したことをより確実にする。

\section{VI. まとめ}

本研究で明らかになった事項を要約すれば次のようになる。

1. 宮城県中 · 北部には姶良 $\mathrm{Tn}$ 火山灰 (AT), 阿蘇 4 火山灰 (Aso-4), 御岳第 1 軽石 (On-PmI), 洞爺火山灰（Toya）の 4 枚の後期更新世広域テフラが, 周辺火山起源の示標テフラに挾まれて存在する。 特に鬼首では後期更新世の広域テフラである Aso-4, On-PmI, Toya がわずか $1.5 \mathrm{~m}$ の堆積物中に認め られる。現時点で鬼首は, On-PmI および Toya の分布のほぼ北限と南限になるが, 各テフラの層厚から みてより遠い地点にまで分布すると予想されるて。

2. 宮城県中部の後期更新世テフラ層序は，上位より順に姶良 $\mathrm{Tn}$ 火山灰（AT)，川崎スコリア層，阿 蘇 4 火山灰 (Aso-4)，愛島軽石層である。同北部では，上位より鳴子潟沼一上原テフラ層，姶良 $\mathrm{Tn}$ 火 山灰 (AT), 鳴子一柳沢テフラ層, 阿蘇 4 火山灰 (Aso-4), 鳴子一荷坂テフラ層, 北原火山灰層, 御岳第 1 軽石 (On-PmI), 洞爺火山灰 (Toya), 一迫軽石層の順で認められる。この結果, 宮城県中・北部におけ るテフラ層序が全国的な第四紀後期のテフラ層序に組み込まれた。特に鬼首において, 御岳第 1 軽石 (On -PmI) と洞爺火山灰（Toya）との間に明確な上下関係を確認できたことは, Toya の層位を, 南関東にお ける後期更新世広域テフラ層序に組み込んだ点で意義がある。またこれより東北地方北部沿岸の垂直隆起 量の大きな地域における 12.5 万年 B.P. から 8 万年 B.P.の間に発達した海成面の存在が支持される。

\section{謝 辞}

小論の作成に際し, 東北大学理学部岩鈗教室の青木謙一郎教授には EPMA の使用をお許しいただい た。また同教室藤巻和宏博士には EPMA の使用にあたり直接御指導いただいた。群馬大学教育学部の新 井房夫教授には，火山ガラスの屈折率を測定していただいた。小論は，筆者の 1 人である早田の東京都立 大学大学院在学中の研究に基つくくころが大きく，その際町田 洋教授にはご指導いただいた。現地調查 にあたって, 宮城県立䉆沢工業高校の梅津譲教諭には快く宿泊の便宜をはかっていただいた。地質調查 
所の奥村晃史博士には，誠に有益なご批判ご討論をいただいた。以上の皆様にここに記して感謝の意を表 します。

最後に1989年 3 月に東北大学理学部を退官された設楽 寛先生に小論を捧げます。

注

1）今回発見した広域テフラ以外に，対比の可能性のあるテフラとして分析したもの全てについてその 結果を示した。

2） AT の上位にある鳴子潟沼一上原テフラ層は，第一近似的に 2 万年頃の噴出と考えられる。

3）Aso-4の下位にある愛島軽石層は，第一近似的に $8 \sim 9$ 万年前の噴出と考えられる。

3） Aso-4 と On-Pm I との間の層準に認められる鳴子一荷坂テフラ層と北原火山層は, 第一近似的に それぞれ $7 \sim 8$ 万年前の噴出と考えられる。

4）一迫軽石層はその上位にToya が認められ，馬場壇 $\mathrm{A}$ 遺跡に㧍いてその下位に赤色土㙵が発達して いる(山田ほか 1986)。従って一迫軽石層の噴出年代は，第一近似的に10 11万年前頃と考えられる。

5）一迫軽石層の上下の層準で発見された旧石器の年代観は，最終間水期頃にまで遡ることになる。

6) 直接的に10万年 B.P. 頃の離水とする資料はないが，サンゴ礁地域で明らかにされた後期更新世海 成段丘編年にあてはめるならその時期の海成段丘に対比される。

7）その後の調查の結果，On-Pm I の分布の北端は岩手県胆沢扇状地であることが明らかとなった（早 田 1989)。

\section{文 献}

新井房夫・町田 洋 (1980)：日本のテフラ・カタログ I 一西南日本〜東北地方の第四紀後期示標テ フラの岩石記載的研究. 軽石学雑誌, 6, 65-76.

Arai, F., Machida, H., OKumura, K., Miyauchi, T., Soda, T. and Yamagata, K. (1986) : Catalogue for late Quaternary marker-tephras in Japan II - Tephras occurring in northeast Honshu and Hokkaido-. Geogr. Rep. Tokyo Metropol. Univ., 21, 223 250.

市川米太 (1983) : 座散乱木遺跡とその周辺遺跡の熱ルミネッセンス年代. 石器文化談話会編「座散乱 木遺跡III 」, 95-96.

- (1986) : 馬場壇 $\mathrm{A}$ 遺跡関連の TL 年代. 東北歴史資料館・石器文化談話会編「馬場壇 A 遺跡 I 一前期旧石器時代の研究一」，東北歴史資料館資料集， 14，131-132.

- (1987) : 青葉山遺跡 B 地点の TL 年代. 東北大学埋蔵文化財調査年報, $2,127-128$.

板垣直俊 (1980)：仙台周辺の 2 つの示標テフラについて. 東北地理, $\mathbf{3 2}, 46$.

一豊島正幸・寺戸恒夫 (1981) : 仙台およびその周辺地㠱に分布する洪積世末期のスコリア層. 東 北地理, 33, 48-53.

蟹沢聰史（1985）：仙台市及び 周辺に分布する愛島軽石とその深成岩質岩片について一噴出源の推定 と極端にそしいトーナル岩の存在一. 岩鉱会誌，80，352-362.

加藤磐雄 - 島田昱郎 (1953) : 栗駒火山西山麓緑色凝灰岩地域の地質及び特に三途川・首鬼湖成層に ついて，岩鉱会誌，39，190-194.

舆水達司 (1983) : 座散乱木遺跡とその周辺のフィッション・トラック年代. 石器文化談話会編「座散 乱木遺跡 III 」, 97-99.

- (1986) : 馬場壇 A 遺跡の火山灰のフィッション・トラック年代. 東北歴史資料館・石器文化談話 会編「馬場壇 $\mathrm{A}$ 遺跡 I - 前期旧石器時代の研究一」，東北歴史資料館資料集，14，133-138.

— (1987) : 愛島軽石層のフィッション・トラック年代. 東北大学埋蔵文化財調查年報, 2, 132-133. (1988)：馬場壇 $\mathrm{A}$ 遺跡およびその周辺のフィッション・トラック年代. 東北歴史資料館・石器文 化談話会編「馬場壇 $\mathrm{A}$ 遺跡 II一前期旧石器時代の研究一」，東北歴史資料館資料集，23，55-64.

町田洋 (1986)：地史を解読する上の鍵層となるテフラ層. 相模原市地形・地質調查会編「相模原の 地形・地質調查報告畫」，第 3 報，4-7.

・・新井房夫 (1983) : 広域テフラと考古学。第四紀研究， 22，133-148.

・鈴木正男 (1971)：火山灰の絶対年代と第四紀後期の編年—フィッション・トラック法による 試み. 科学, 41, 263-270.

一一新井房夫 ・百瀬 貢 (1985)：阿蘇 4 火山灰一一分布の広域性と後期更新世示標層としての意 
義. 火山，第 2 集，30，129-145.

- - - - 宮内崇裕・奥村晃史 (1987）：北日本を広く覆う洞爺火山灰. 第四紀研究， 26, 129-145.

ㄴ..… 小田静夫・遠藤邦彦・杉原重夫 (1984) : テフラと日本考古学—考古学研究と関係する

テフラのカタログー。渡辺直経編「古文化財に関する保存科学と人文・自然科学」，86, 5-928.

松本英二・前田保夫 - 竹村恵二 - 西田史朗 (1987)：姶良 Tn (AT) $)^{{ }^{14}} \mathrm{C}$ 年代. 第四紀研究, 26, 79-83.

宮内崇裕（1988）：東北地方北部における後期更新世海成面の対比と編年，地理評，61，404-422.

中井信之 (1988)：放射性炭素年代測定結果の報告. 東北歴史資料館・石器文化談話会編「馬場壇 $\mathrm{A}$ 遺 II - - 前旧石器時代の研究——」，東北歴史資料館資料集，23，52.

小元久仁夫（1964）：宮城県鬼首盆地の地形発達史，東北地理， 16, 61-70.

（1966）：宮城県鳴子盈地の地形発達史，地理評，39，521-537.

Омото (1983): Radiocarbon dating using a low-background liquid scintillation counting system. Sci. Rep. Tohoku Univ., 7th ser., 33, 23-43.

佐藤高晴（1987）：青葉山遺跡 B 地点の火山灰の ESR 年代，東北大学埋蔵文化財調查年報，2，129130.

早田 勉（1984）：鳴子火山から噴出した第四紀後期のテフラ．火山，第 2 集，29，338.

는.（1988）：旧石器時代の示標テフラ。日本第四紀学会講演要旨集，18，14-17.

(1989)：テフロクロノロジーによる前期旧石器時代遺物包含層の検討一仙台平野北部の遺跡を 中心に. 第四紀研究，(投稿中).

庄子貞雄 • 山田一郎 - 高橋 正 (1983) : 座散乱木遺跡を中心とした遺跡土壌の土壤学的研究. 石器文 化談話会編「座散乱木遺跡 III 」, 80-94.

須藤 隆 - 梶原 洋 - 佐川正敏 (1985) : 青葉山 B 遺跡の調查成果. 日本考古学協会第51回総会研究発 表要旨, 13-14.

東北歴史資料館 - 石器文化談話会 (1986)：馬場壇 $\mathrm{A}$ 遺跡と層序. 東北歴史資料館 - 石器文化談話会編 「馬場壇 A 遺跡 I一D前期旧石器時代の研究—」，東北歴史資料館資料集，14，1-25.

宇井忠英・杉村 新. 芝橋敬一 (1973) : 肘折火砕流堆積物の ${ }^{14} \mathrm{C}$ 年代. 火山，第 2 集，8，171-172. 八木浩司. 宮内崇裕 (1986) : 能代平野北部に打ける洞爺火山灰の発見とその編年学上の意味. 東北地 理, 38, 236-237.

YAMADA, E. (1972) : Study on the stratigraphy of Onikobe area, Miyagi Prefecture, Japan with special reference to the development of the Onikobe Basin-. Geol. Surv. Japan Bull., 23, 217-231.

山田一郎・庄子貞雄（1983）：火山ガラスの性質ならびに火山帯とテフラの性質との関係について. 日 本土塎肥料学雑誌, $\mathbf{5 4}, 311-318$.

- - - 阿部 隆 (1986)：馬場壇 A 遺跡を中心とする旧石器時代遺跡土培の土袞学的検討. 東北 歴史資料館 - 石器文化談話会編「馬場壇 $\mathrm{A}$ 遺跡 I一—前期旧石器時代の研究——」, 東北歴史資料館 資料集，14，118-122.

米地文夫・菊池強一（1966）：尾花沢軽石層について。東北地理，18，23-28.

(1989年 5 月 16 日受付，1989年10月 16 日受理) 